\title{
Triatoma rubrovaria (Blanchard, 1843) (Hemiptera, Reduviidae, Triatominae) II: Trophic Resources and Ecological Observations of Five Populations Collected in the State of Rio Grande do Sul, Brazil
}

\author{
Carlos Eduardo Almeida/***+ ${ }^{+}$, Rosemere Duarte**, Raquel Guerra do Nascimento**, \\ Raquel S Pacheco*, Jane Costa
}

\begin{abstract}
Núcleo de Informatização, Coleção Entomológica, Departamento de Entomologia *Laboratório de Sistemática Bioquímica, Instituto Oswaldo Cruz-Fiocruz, Av. Brasil 4365, 21045-900 Rio de Janeiro, RJ, Brasil **Laboratório de Imunodiagnóstico, Escola Nacional de Saúde Pública-Fiocruz, Rio de Janeiro, RJ, Brasil ***Núcleo Avançado de Estudos de Vetores e Artrópodes Peçonhentos, Museu de Ciências, Centro Universitário de Barra Mansa, Barra Mansa, RJ, Brasil
\end{abstract}

Triatoma rubrovaria has become the most frequently captured triatomine species after the control of $\mathrm{T}$. infestans in the State of Rio Grande do Sul (RS), Brazil. Isoenzymatic and chromatic studies indicate the existence of, at least, two distinct phenotypic patterns of T. rubrovaria in RS. The geographic variation noted through molecular tools may also result in distinct profiles of vectorial potentiality. In order to enhance our understanding of the bionomic knowledge of $\mathrm{T}$. rubrovaria separate batches of the species were collected from different municipalities of RS distant from 72 to 332 km: Santana do Livramento (natural ecotope), Santana do Livramento (artificial ecotope), Santiago (natural ecotope), Canguçu (peridomicile) and Encruzilhada do Sul (natural ecotope). A total of 285 specimens were collected, 85 specimens kept sufficient fecal material in their guts for the precipitin analysis. The results indicated the food eclecticism for this species and the anti-rodent serum showed the highest positivity in most localities. From the total of analyzed samples, only $1.3 \%$ of unique positivity for human blood was registered, all of them for Santiago population. This reactivity to human blood may be associated to pastures activities in the field.

Key words: Triatoma rubrovaria - ecological observations - ecotopes - trophic resource - Rio Grande do Sul - Brazil

Triatoma rubrovaria (Blanchard, 1843) (Hemiptera, Reduviidae, Triatominae) is widespread in Uruguay and in some neighboring parts of Northeastern Argentina, where it is mainly found among exfoliate rocks known as 'pedregales'. It is considered a generalist species, feeding from a wide variety of vertebrate and invertebrate hosts (Salvatella et al. 1994, 1995). In Brazil, its geographic distribution has been confirmed only in the southern states of Paraná and Rio Grande do Sul (RS). Lent (1942) mentions $T$. rubrovaria (cited as Eutriatoma rubrovaria) as an exclusively sylvatic species found in rockpiles and peridomestic habitats in RS, but only rarely encountered in human dwellings. In following years, many authors have also mentioned the finding of this species in domestic habitats, but with no indication of successful domestic colonization (Di Primo 1957, Lucena 1959, Correa 1968, Lent \& Wygodzinsky 1979). However, its potential for colonizing human dwellings was recognized by Silveira and Rezende (1994). Salvatella et al. (1994) demonstrated that it does feed on humans. Further Silva and Silva (1993)

Supported by Brazilian National Health Foundation, agreement term no.1159/98 and The State of Rio de Janeiro, Brazil, Research Foundation.

${ }^{+}$Corresponding author. Fax: +55-21-2590.3545. E-mail: almeidace@ioc.fiocruz.br

Received 26 March 2002

Accepted 5 September 2002 concluded that it is a experimentally highly competent vector of Trypanosoma cruzi, causative agent of Chagas disease.

The analysis on surveillance data of $T$. rubrovaria gathered by the Brazilian National Health Foundation (Funasa) during the Chagas Disease Control Program revealed the increasing presence of $T$. rubrovaria in houses in rural areas of RS. It has shown that this species is progressively invading houses in areas where the main domestic vector of Chagas disease, Triatoma infestans, has been eliminated through vector control interventions (Almeida et al. 2000).

We have earlier reported the chromatic and isoenzymatic variability of $T$. rubrovaria in different municipalities of RS, showing the existence of, at least, two distinct populations genetically isolated in this state (Almeida et al. 2002). In order to extend our understanding of the bionomic knowledge of $T$. rubrovaria, field captures were performed, and the possible trophic resources were analyzed, and correlated to ecological and epidemiological aspects in different localities of RS.

\section{MATERIALS AND METHODS}

Studied areas - Specimens for this study were collected in batches from four municipalities of the State of RS: Santana do Livramento (3053'27'S; 55'31'58'W), Santiago (29¹1'30'S ; 54 52'02'W), Canguçu (31 '23'42'S; $\left.52^{\circ} 40^{\prime} 32^{\prime \prime} \mathrm{W}\right)$ and Encruzilhada do Sul (30³2'38'S; $\left.52^{\circ} 31^{\prime} 19^{\prime \prime} \mathrm{W}\right)$, where savanna-like or steppe-like subtropical mixed prairies are the predominant environmental characteristics. Those areas have been chosen aiming to ob- 
tain a varied sampling within the current geographic distribution of T. rubrovaria in RS, and also according to the notification of the domiciliary invasion by this species (Almeida et al. 2000, and technical board information of Funasa). The selection of those areas has also been based on the phenotypic variance shown for T. rubrovaria by Almeida et al. (2002). The distances (km) among the collection sites are given in the Figure.

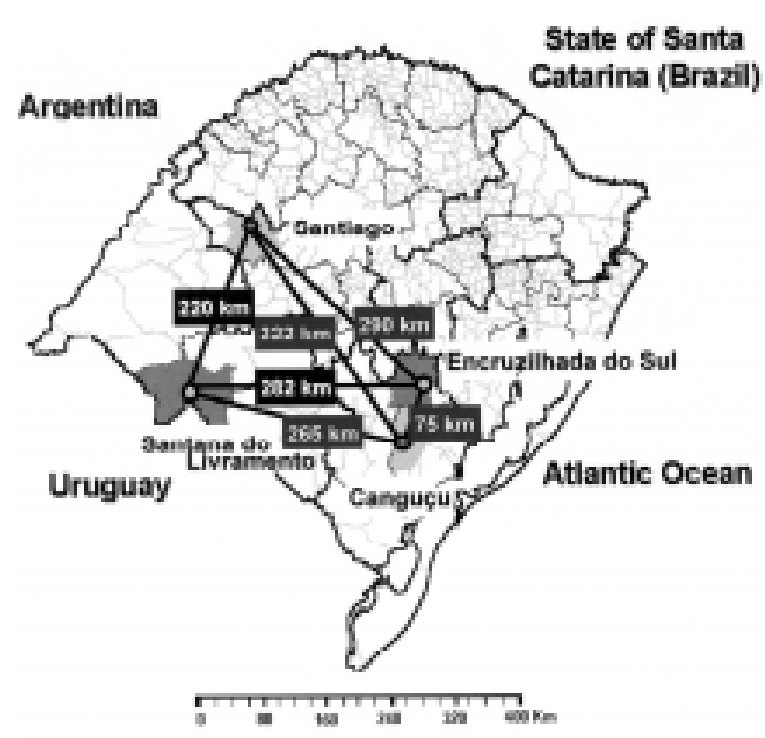

Map showing the geographic distance (in $\mathrm{km}$ ) among the sites where Triatoma rubrovaria was collected in the State of Rio Grande do Sul.

The sylvatic-like environment, here called "ruderal", is located more than $50 \mathrm{~m}$ away from houses, where cattle and sheep are frequently found in the pasture, but sylvatic animals are less common. This environment is characterized by grass culture to feed the cattle where dry overlapping stones sheltering triatomines are found.

Inspections and captures at peridomiciliary, domiciliary, natural ecotope in ruderal environment, and artificial ecotope in ruderal environment, were performed in all above-mentioned municipalities. One visit was also made to the sylvatic environment in the municipality of Canguçu. Inspections and captures were carried out in the warm season from October to March (1998-2001). The peridomiciliary habitats, considered as ranging from 5 to $10 \mathrm{~m}$ around houses, were frequently delimited by stone walls: a rudimentary wall built by overlapping rocks. The most frequent domestic animals found in this area were chickens, dogs, cattle and sheep.

Insects - The insects collected were placed in plastic bottles containing filter paper and transported to the laboratory. The morphologic identification of adults was performed according to Lent and Wygodzinsky (1979).

For the precipitin test, the standard protocols were carried out according to the published protocols of Weitz (1956) and Siqueira (1960). Rabbit sera immunized with total proteins of human blood and that of domestic and sylvatic animals, including cat (Felis domesticus), dog
(Canis familiaris), horse (Equus caballus), lizard (Sauria: Iguanidae), opossum (Didelphis marsupialis), rodent (Rattus norvegicus) and sheep (Ovis aires) were used. Each triatomine collected was pressed dorsoventrally at the abdominal region and the feces drops were placed on strips of filter paper (Klabin no. 80). This procedure allowed to keep the insects alive for further laboratory tests. After drying all the samples were stored away at $2-8^{\circ} \mathrm{C}$. For the test, a $0.5 \mathrm{~cm}$ diameter cut was made in the papers containing the samples, which were eluted in $500 \mu$ of PBS (phosphate buffered saline) and left overnight in the refrigerator. Each eluate was tested with the eight antisera mentioned above. To begin with, $50 \mu \mathrm{l}$ of antiserum were poured in a glass capillary. Next, the same volume of the sample was slowly poured so both, instead of mixing, form a contact surface with each other. It is in this interface that the sample antigens get into contact with the antiserum antibodies. When they have an adequate concentration, a precipitation ring is formed. The reading was performed every $30 \mathrm{~min}$ for $2 \mathrm{~h}$.

Each sample was read by two technicians and, whenever necessary the tests were repeated to confirm the results. Positive controls (antiserum + homologous protein) and negative controls (antiserum + PBS) were added in each test.

\section{RESULTS}

In Santana do Livramento, specimens of T. rubrovaria were collected in natural ecotopes (overlapping rocks for 'Ln' population) and in artificial ones (stone walls for ' $\mathrm{La}$ ' population). In both cases, they were located in ruderal environments. In Canguçu, they were found only in stone walls in the peridomicile and were designated as ' $\mathrm{C}$ ' population. In Santiago and Encruzilhada do Sul specimens were found only in natural ecotopes located in ruderal environments, called ' $S$ ' and 'E' populations, respectively (Table I).

A total of 574 triatomines of the following species were collected: T. rubrovaria $(\mathrm{n}=285)$, . . circummaculata $(\mathrm{Stal}$, 1859) $(\mathrm{n}=288)$ and $T$. carcavalloi Jurberg, Rocha \& Lent, $1998(\mathrm{n}=1)$. In the present work, the occurrence of $T$. carcavalloi was registered in the municipality of Encruzilhada do Sul. A female specimen was collected in nymphal stage reaching the adulthood in the laboratory.

Trophic resources - T. circummaculata and $T$. carcavallo $i$ were not used in the precipitin test, since it was not possible to obtain fecal material by abdominal compression. Eighty-five specimens of T. rubrovaria were examined in Santana do Livramento $(\mathrm{n}=37)$, Canguçu $[\mathrm{n}=30$ (peridomicile)] and Santiago $(\mathrm{n}=18)$. From the total of specimens analyzed $17.9 \%$ did not show positivity to any of the antisera utilized. On the other hand, $82 \%$ $(n=64)$ showed positivity, highlighted by the rodent antiserum, which presented the highest rate $(30.8 \%)$ followed by the opossum (15.4\%), sheep (14.1\%), dog and reptile (both $7.7 \%$ ), cat and horse (both $2.6 \%$ ). A small reactivity to human blood (1.3\%) was registered (Table II). Seven samples showed double positive reactions: five were positive to dog and rodent association, one was positive to opossum and rodent association and one was positive to both sheep and man. 
In the peridomestic environment in Canguçu, the highest positivity was observed to rodent blood (24.1\%). No isolated sample was tested positive to human in this ecotope, but it was detected through the sheep/human association. The samples from Santana do Livramento, both from artificial and natural environments also showed the higher positivity rate to rodent blood $(42.1 \%$ and $35.7 \%$, respectively) and $0 \%$ to human. In natural ecotope in this municipality, the second most reactive blood sources were opossum and reptile blood (both at $15.8 \%$ ), and in artificial one ovine blood (21.4\%). In the ruderal environment of Santiago the highest positivity was observed for opossum blood (31.2\%). No reactivity was observed for cat, horse and lizard bloods. Individual fecal samples from this locality showed $1.3 \%$ of positivity for human blood (Table II).

Ecological observations - T. rubrovaria was always found in typical ecotopes in the ruderal area, which were characterized by loose and overlapping rocks in dry environments on the prairies. In all visited municipalities in these dry environment, the artropodofauna has generally been represented by $T$. rubrovaria in association with the cockroach Blaptica dubia and in some cases, with $T$. circummaculata. T. rubrovaria was not collected in humid rock formations where the fauna is more diversified, having been observed and registered the occurrence of lizards, amphibians (Anura), crickets, ants, lepidopterous larvae, chilopods, diplopods, daddy-long-legs (Opiliones), scorpions and spiders.

In all the localities visited the environments defined as ruderal, which were positive to T. rubrovaria, were located more than $50 \mathrm{~m}$ away from any domicile and presented a very altered vegetation, due to farming activity. These environments were located within rural properties, where eventually humans and domestic animals, such as ovine, bovine, equine and dogs circulate.

From the five municipalities analyzed, $T$. rubrovaria was found in peridomiciliary areas only in Canguçu. Seventy-three specimens found housed between walls built of overlapping stones in the peridomicile (Table I). Near this stonewall, but within the ruderal environment, 212 triatomines samples were collected. From this group, 201 were $T$. circummaculata and only 11 were $T$. rubrovaria. In Canguçu, a forest area was visited, where part of the vegetation was preserved. In this locality called Cerro da Boneca, triatomines were only collected without the preserved area. The walls where T. rubrovaria was registered were more humid ecotopes than the rock formations where this species was found in the wild environment.

In Piratini and Encruzilhada do Sul, where the predominance of $T$. circummaculata was verified, only the ruderal areas were positive to the presence of $T$. rubrovaria.

TABLE I

Collecting sites in the State of Rio Grande do Sul and number of collected specimens of Triatoma rubrovaria (Tr) and T. circummaculata $(\mathrm{Tc})$

\begin{tabular}{|c|c|c|c|c|c|c|c|}
\hline Environments & & $\begin{array}{c}\text { Santana do } \\
\text { Livramento } \\
\operatorname{Tr} / \mathrm{Tc}\end{array}$ & $\begin{array}{l}\text { Piratini } \\
\text { Tr / Tc }\end{array}$ & $\begin{array}{c}\text { Encruzilhada } \\
\text { do Sul } \\
\operatorname{Tr} / \mathrm{Tc} \\
\end{array}$ & $\begin{array}{c}\text { Canguçu } \\
\operatorname{Tr} / \mathrm{Tc}\end{array}$ & $\begin{array}{c}\text { Santiago } \\
\mathrm{Tr} / \mathrm{Tc}\end{array}$ & Total \\
\hline Peridomiciliary & & $0 / 0$ & $0 / 0$ & $0 / 0$ & $73 / 0$ & $0 / 0$ & 73 \\
\hline Domiciliary & & $0 / 0$ & $0 / 0$ & $0 / 0$ & $0 / 0$ & $0 / 0$ & 0 \\
\hline & $\begin{array}{l}\text { Natural } \\
\text { ecotope }\end{array}$ & $58 / 0$ & $0 / 43$ & $17 / 44$ & $11 / 201$ & $78 / 0$ & 452 \\
\hline Ruderal & $\begin{array}{l}\text { Artificial } \\
\text { ecotope }\end{array}$ & $41 / 0$ & $7 / 0$ & $0 / 0$ & $0 / 0$ & $0 / 0$ & 48 \\
\hline Total & & $99 / 0$ & $7 / 43$ & $17 / 44$ & 84 / 201 & $78 / 0$ & 573 \\
\hline
\end{tabular}

One specimen of T. carcavalloi on nymphal stage was collected in the municipality of Encruzilhada do Sul in natural environment on ruderal ecotope.

TABLE II

Percentage of reactivity of Triatoma rubrovaria feces to eight different antisera tested by the precipitin test

\begin{tabular}{lccccccccrr}
\hline & & \multicolumn{10}{c}{ Antiserum } \\
\cline { 3 - 10 } Population & $n$ & Cat & Dog & Horse & Lizard & Opossum & Rodent & Sheep & Man & Without \\
reactivity \\
\hline Ln & 19 & 5.26 & 5.26 & 0.00 & 15.79 & 15.79 & 42.11 & 10.53 & 0.00 & 5.26 \\
La & 14 & 0.00 & 0.00 & 7.14 & 7.14 & 14.29 & 35.71 & 21.43 & 0.00 & 14.29 \\
S & 16 & 0.00 & 12.50 & 0.00 & 0.00 & 31.25 & 25.00 & 12.50 & 6.25 & 12.50 \\
C & 29 & 3.45 & 10.34 & 3.45 & 6.90 & 6.90 & 24.14 & 13.79 & 0.00 & 31.03 \\
\hline Total & 78 & 2.56 & 7.69 & 2.56 & 7.69 & 15.38 & 30.77 & 14.10 & 1.28 & 17.95 \\
\hline
\end{tabular}

Ln: ruderal population of T. rubrovaria collected in natural ecotope (overlap stones), in the municipality of Santana do Livramento; La: ruderal population of T. rubrovaria collected in artificial ecotope (stone walls), in the municipality of Santana do Livramento; S: ruderal population of T. rubrovaria collected in natural ecotope (overlap stones), in the municipality of Santiago; C: peridomestic population of $T$. rubrovaria collected in artificial ecotope (stone walls) in the municipality of Canguçu. 


\section{DISCUSSION}

Because most of the insects collected had no fecal material in their guts, only 85 out 285 T. rubrovaria specimens collected were analyzed by the precipitin test. Salvatella et al. (1994) also called attention to the lack of gut content of the specimens collected in the locality " $\mathrm{La}$ Bolsa" in Uruguay. This fact may indicate lack of regular food source in the field and may explain, in part, the domiciliary invasion process for $T$. rubrovaria (Almeida et al. 2000).

Trophic resources - A total of $17.5 \%$ of the samples were non-reactive to the eight antisera used in this study. This result could be correlated to the fact that in the field, T. rubrovaria may be feeding on different food sources from those tested in this study. Lorosa et al. (2000a) showed under laboratorial conditions, that this species is able to complete its life cycle feeding just on B. dubia. It is important to mention that $B$. dubia and $T$. circummaculata are the most frequently found arthopods in cohabitation with T. rubrovaria. As addressed by Salvatella et al. (1994) there is evidence indicating that the use of $B$. dubia haemolimphe as food source is more frequent in the absence of haematophagy. However, such food source was not tested in this study.

The results obtained by the precipitin test showed the feeding eclecticism of $T$. rubrovaria corroborating with the results of Salvatella et al. (1994) for the same species in Uruguay. However, contrary to the $63 \%$ of positivity to more than one blood source observed by this author, in our study only $5.8 \%$ with double positivity were observed.

The highest rate of positivity was found for rodent blood in most of the localities studied. This is in agreement to the results earlier reported by Lorosa et al. (2000b). However, for the specimens collected in ruderal environment in Santiago, the highest rate was found for opossum blood (31.2\%) followed by the rodent one (25\%). Rodent feces were frequently observed between cracks in rocky and holes shelters near the ecotopes where $T$. rubrovaria was collected. According to the description of the ecotopes and the occurrence of rodents in RS reported by Moojen (1952), "Rato do Chão" (Akodon arenicola), "Ratos do Mato" (Thomasomys oenax and T. lechei), and "Camundongo do Mato" (Oryzomys flavescens) are probably be the most frequent food sources of $T$. rubrovaria. In the locality of La Bolsa, Uruguay, Salvatella et al. (1995) registered T. rubrovaria cohabiting with rodents in $6.6 \%$ of the ecotopes.

In the present study, and in data obtained from the precipitin test, only $1.3 \%$ of unique positivity to the human blood was found and one double positive sample to human/sheep blood, suggesting that $T$. rubrovaria is not closely associated to man, but otherwise to domestic and synanthropic animals.

Ecological observations - As already observed by Salvatella et al. (1995) in Uruguay, T. rubrovaria prefers dry environments, where it cohabitates with $T$. circummaculata and with B. dubia. Apparently, in these environments, the general biomass is scarcer, because the trophic resources are also restricted. These ecotopes are characterized by dry overlapping stones or on the dry soil, showing lack of decomposing organic matter. Consequently, the saprophytic and arthropod fauna are apparently poorer in diversity and abundance at these environments.

Because covering vegetation in the collection sites and in a large portion of the pampas in RS was altered due to the practice of farming activities, the observed increasing of the domiciliary invasion process of $T$. rubrovaria mentioned by Almeida et al. (2000) may be caused by this environmental modifications. The replacement of the native flora may have favored the increasing of the population density of $T$. rubrovaria, intensified by the removal of predator's fauna. It was noted during the captures, the existence of numerous starving colonies of T. rubrovaria. Although they were starving, numerous colonies indicate the presence of enough trophic resources to promote and maintain high populational densities of $T$. rubrovaria in the ruderal environment. In these anthropic environments, probably, T. rubrovaria has found favorable development conditions, since its trophic resources were maintained, and even incremented due to the introduction of domestic animals.

Forattini el al. (1971a) altered the vegetation surrounding experimental shelters, and verified the rise of the population density and migration of $T$. sordida. Forattini et al. (1971b) emphasized that the unaltered environment induces the populational equilibrium of this species; in these natural conditions, $T$. sordida finds barriers to increase its population density due mainly to: (i) the presence of predators, (ii) limitation food sources, and (iii) restricted available shelters.

In a parallel analysis, according to the conclusions of Forattini et al. (1971b) for T. sordida, a similar phenomenon may be occurring in case of T. rubrovaria. This species had probably kept itself under control until the environmental changes occurred, which favored its population increase as a result of ecological disturbance, and not as a result of the niche occupied by $T$. infestans until its control. However, the possibility of simultaneous actions of these two factors may also be taken into account.

Data compiled by Funasa show that the domiciliary invasion of T. rubrovaria occurs by flight during the hot months. For T. guasayana, it was noted that the females invade the domicile by flying, performing oviposition of viable eggs, indicating that the flight of the triatomines may be the result of the necessity of exploration of new resources for the offspring (Gajate et al. 1996). In the hypothesis that this fact may occur with $T$. rubrovaria, the risk of the installation of intradomiciliary colonies must be considered.

In this study, only Canguçu municipality was positive for $T$. rubrovaria in the peridomicile, where two colonies were clearly well established in a stonewall near the domiciles. In one site, 51 specimens were collected, and in the other 22; all of them were nymphs in different stages. Exhaustive searches carried out in eight different localities in the ruderal environments in Canguçu resulted in only 11 specimens of $T$. rubrovaria and 201 of $T$. circummaculata. Because T. rubrovaria is frequently found cohabiting with $T$. circummaculata in various other localities, it seems that the ruderal environment in Canguçu 
favors the triatomine fauna. In this same municipality, the occurrence of $T$. circummaculata in the peridomicile was not registered. This fact stresses the wide capacity of peridomiciliary colonization for T. rubrovaria.

Data from precipitin test, associated with the ecological observations, suggest that, currently, adults of $T$. rubrovaria have been invading the domicile. However, no clues of colonization or of human blood utilization as a frequent food source, were registered. With respect to the biological characteristics of T. rubrovaria, it is important to maintain the epidemiological vigilance and to carry out studies on bionomic aspects of its vector capability, such as the intermoult period, resistance to starvation and feeding and defecation patterns.

\section{ACKNOWLEDGEMENTS}

To the technicians of Funasa for the valuable support during the field captures. To Dr Pradeep Ghosh (National Institutes of Health) for helpful suggestions and the critical reading of the manuscript.

\section{REFERENCES}

Almeida CE, Pacheco RS, Noireau F, Costa J 2002. Triatoma rubrovaria (Blanchard, 1843) (Hemiptera, Reduviidae, Triatominae) I: isoenzymatic and chromatic studies of five populations collected in the State of Rio Grande do Sul, Brazil. Mem Inst Oswaldo Cruz 97: 829-834.

Almeida CE, Vinhaes MC, Almeida JR, Silveira AC, Costa J 2000. Monitoring the domiciliary and peridomiciliary invasion process of Triatoma rubrovaria in the State of Rio Grande do Sul, Brazil. Mem Inst Oswaldo Cruz 95: 761-768.

Corrêa RR 1968. Informe sobre a doença de Chagas no Brasil e em especial no estado de São Paulo. Rev Bras Malariol Doenç Trop 20: 39-81.

Di Primo P 1957. Atual distribuição geográfica dos triatomídeos e seus índices de infecção no Rio Grande do Sul. An Fac Med Porto Alegre 17: 17-37.

Forattini OP, Ferreira OA, Rocha-Silva EO, Rabello EX, Santos JL 1971a. Aspectos ecológicos da tripanosomose Americana. II-Distribuição e dispersão de triatomíneos em ecótopos naturais e artificiais. Rev Saúde Pub 5: 163-192.

Forattini OP, Rocha-Silva EO, Ferreira OA, Rabello EX, Pattoli DG 1971b. Aspectos ecológicos da tripanosomose Americana. III-Dispersão local de triatomíneos, com especial atenção ao Triatoma sordida. Rev Saúde Pub 5: 193-205.

Gajate PP, Bottazzi MV, Pietrokovsky SM, Wisnivesky-Colli C 1996. Potential colonization of the peridomicile by Triatoma guasayana (Hemiptera:Reduviidae) in Santiago del
Estero, Argentina. J Med Entomol 33: 635-639.

Jurberg J, Rocha DS, Lorosa ES, Vinhaes MC, Lent H 1998. Uma nova espécie de Triatoma do Estado do Rio Grande do Sul, Brasil (Hemiptera, Reduviidae, Triatominae). Entomol Vect 5: 295-310.

Lent H 1942. Estudos sobre os triatomíneos do Estado do Rio Grande do Sul, com descrição de uma espécie nova. Rev Bras Biol 2: 219-231.

Lent H, Wygodzinsky P 1979. Revision of the Triatominae (Hemiptera, Reduviidae), and their significance as vectors as Chagas' disease. Bul Am Mus of Nat Hist 163: 127-520.

Lorosa ES, Jurberg J, Souza ALA, Vinhaes MC, Nunes IM 2000a. Hemolinfa de dictioptera na manutenção do ciclo biológico silvestre de Triatoma rubrovaria (Blanchard 1843) e Triatoma circummaculata (Stal, 1859) (Hemiptera, Reduviidade, Triatominae). Entomol Vect 7: 287-296.

Lorosa ES, Nunes IM, Vinhaes MC, Andrade RE, Jurberg J 2000b. Preferência alimentar de algumas espécies de triatomíneos capturados no estado do Rio Grande do Sul, Brasil, com auxílio da técnica de precipitina e grau de infectividade. Entomol Vect 7: 211-225.

Lucena DT 1959. Ecologia dos triatomíneos no Brasil. Rev Bras Malariol Doenç Trop 11: 577-635.

Moojen J 1952. Os Roedores do Brasil, Instituto Nacional do Livro, Série A-II, Rio de Janeiro, 70 pp.

Salvatella R, Calegari L, Puime A, Basmadjian Y, Rosa R, Guerrero J, Martinez M, Mendaro G, Briano D, Montero C, Wisniversky-Colli C 1994. Perfil alimentario de Triatoma rubrovaria (Blanchard, 1843) (Hemiptera, Triatominae) en ámbitos peridomiciliarios, de una localidad rural de Uruguay. Rev Inst Med Trop São Paulo 36: 311-320.

Salvatella R, Rosa R, Basmadjian Y, Puime A, Calegari L, Guerrero J, Martinez M, Mendaro G, Briano D, Montero C, Wisnivesky-Colli C 1995. Ecology of Triatoma rubrovaria (Hemiptera, Triatominae) in wild and peridomestic environments of Uruguay. Mem Inst Oswaldo Cruz, 90: 325-328.

Silva IG, Silva HHG 1993. Suscetibilidade de 11 espécies de triatomíneos (Hemiptera, Reduviidae) à cepa ' $\mathrm{Y}$ ' de Trypanosoma cruzi (Kinetoplastida, Trypanosomatidae). Rev Bras Ent 37: 459-463.

Silveira AC, Rezende DF 1994. Epidemiologia e controle da transmissão vetorial da doença de Chagas no Brasil. Rev Soc Bras Med Trop 27 (Supl. 3): 11- 22.

Siqueira AF 1960. Estudos sobre a reação de precipina aplicada à identificação de sangue ingerido por triatomíneos. Rev Inst Med Trop São Paulo 2: 41-58.

Weitz B 1956. Identification of bloodsucking arthropods. Bull WHO 15: 473-479. 